\title{
Sentence Enforcement Postponement of and Penalty Suspension in Legal Entities
}

\author{
Hossein Ranjbar \\ Assistant Professor at Department of Law, Shomal University \\ h.ranjbar95@gmail.com \\ Yousef Nouraei
}

Assistant Professor at Department of Law, Shomal University

dr.yoosofnoorai@gmail.com

Mehrdad Rokni

Master's student in Jurisprudence and criminal law, Shomal University, Corresponding Author mehrdad_rk@yahoo.com

\section{Doi:10.5901/mjss.2016.v7n5s1p119}

\section{Abstract}

The sentence enforcement postponement is a new law derived from the French legal system without any history in Iranian law prior to it; and the penalty suspension has been initially considered in new Islamic Penal Code (IPC) (passed in 2013) and its correlation seems interesting with legal entity who has criminal responsibility in this law for the first time. Therefore, we should find whether the postponement or suspension is suitable for legal entities according to two important hypotheses? The legal entity is created from society, association and solidarity of individuals or real people. However, the legislator considers all conditions in Article 40 of postponement, and thus he does not consider any postponement or suspension for legal entity, but in the case of considering the criminal responsibility for legal entity like a real person as an individual, we can argue that he can have a variety of states and situations like a human being and do the right or wrong deed in society. When the legislator gives him life and considers responsibility for him, the legal entity will be included in postponement or suspension according to law and descriptions because when the legislator creates the criminal responsibility for legal entity, we should consider the criminal responsibility components for him.

Keywords: Sentence enforcement postponement, penalty suspension, simple postponement, surveillance postponement, legal entities

\section{Introduction}

Islamic Penal Code (IPC) of Iran was enacted in 2013 and first discussed the Articles 20 and 143 of criminal responsibility for legal entities. The penalty suspension in Article 46 and Sentence enforcement postponement in Article 40 are first included in the same law. The law considers the criminal responsibility for legal entity if his legal representative commits crime for his benefits. However, it should be noted that the legal entity lives in society in a way that he has right or wrong deed in communicating with other people. The commutation aspect is another condition for postponement and it can be attributed to legal equities according to brain equality theory (Ranjbar, 2014). Even the other conditions of postponement including the anticipated offender correction and loss compensation or lack of effective criminal record can be applied for legal entities. Article 46 of Islamic Penal Code adopted in 2013 also refers to penalty suspension and its conditions. In general, the legislator considers all conditions in Article 40 of Islamic Penal Code adopted in 2013. According to this introduction, we examine the two important hypotheses about inclusion or exclusion of sentence enforcement postponement and penalty suspension for legal entities.

\section{Problem Statement}

The questions which should be answered in this article are as follows: 1- Is it possible to consider the sentence enforcement postponement for legal entity? 2- Is it possible to consider the penalty suspension for legal entity? 3- What strategies does the legislator consider for using these legal articles? 4- What is the legislator's purpose of creating these legal articles in Islamic Penal Code? 5- What conditions should be existed for verdict of sentence enforcement postponement and penalty suspension? 6- Can we apply the commutation aspects for legal entities? 


\section{Definitions}

Legal entity consists of the community, association and solidarity of human or real individuals in order to accomplish a specific purpose, whether profit or nonprofit, under the terms and provisions of law (Nourbaha, 2011). Criminal responsibility means imposition of penalty to subject who has the ability or capacity of criminal punishment (Ranjbar, ibid). The conclusion of these two definitions will result in definition of criminal responsibility which has first been considered in new Islamic Penal Code. The penalty suspension means that the sentence enforcement court suspends the punishment in appeal according to the terms and for a certain time in order to correct the offender. The postponement literally means preventing and delaying (Moin Dictionary, 1983). The sentence enforcement postponement means the competent court power to postponing the sentence enforcement after criminalizing the offender (Hungerfor, 2000). The simple sentence enforcement postponement means that the court postpones the penalty and frees the criminal unlimitedly after authenticating the accuser's guilt without determining punishment for him. The supervised enforcement postponement is like the simple postponement, but in addition to the conditions for enforcing the simple postponement, the offender is committed to implement the orders and measures determined by court timely during the postponement.

\section{Suspension or Postponement of Legal Entities}

According to the bills and legal regulations of other countries, the sentence enforcement postponement is one of the special arrangements for investigating the juvenile delinquency because this institution prefers the "necessity for sentence enforcement after examining the juvenile's case" to data-based legal formalities. Therefore, this type of investigation arrangement is used more in hearings for children and adolescents, but it is not applied in youth crime. For instance, in hearings for up-to-13-year-old male criminals in courts of England, most common sentence was sentence enforcement postponement for them, so that the courts voted for sentence enforcement postponement in 52 percent of criminals. Nowadays, however, the postponement is absolutely considered in most of the countries (such as France and Germany) and it is also applied in adults because if the philosophy of this institution is prevention of punishing the nondangerous criminals, this institution can be applied for both categories of German offenders. Therefore, the French legislators (in Articles 59 and 60) have not considered a certain age group and the criminal will have this legal leniency if he has conditions written in those laws. The sentence enforcement postponement is not among the penalty successors, but it is among the condonation issues in which the neglect of trial is conditional. Two hypotheses of this paper are as follows:

First hypothesis: Legal entities are involved in sentence enforcement postponement and penalty suspension.

Second hypothesis: Legal entities are not involved in sentence enforcement postponement and penalty suspension.

\section{First Hypothesis Study}

According to the law, it can be perceived that the legal entities are involved in suspension or postponement. According to Article 40, in crimes with Tazir (punishment) grades 6 to 8, the court can postpone the sentence enforcement for 6 months to 2 years based on conditions after approving the offender's guilt considering his individual, familial and social situations and background and circumstances which have led to commitment of crime. Now, if we consider the legal entity as a real person with criminal responsibility, the personal situation covers the legal entity as he may have moods and situations like the social situation. When the legislator gives him life and considers responsibility for him and he lives in the community and has right or wrong deed and affects the other people or legal entities in communication with them, his social status should be considered, and thus the sentence enforcement postponement is considered for him from this perspective provided that we accept the hypothesis under which the legislator has not considered the sum of these situations. However, when it comes to familial status, we can certainly conclude that the legislator has considered the legal entity according to the available definitions of family, and thus there is not any doubt about this case. Here, we can claim that the legislator has considered these three separated cases as well as the real person and legal entity as some of these cases include the real person and the others cover the legal entity. In the case of crime background and circumstances, it should be noted that the legal entity can also records like a real person. Excepting the family status, if we consider the personal and social status for legal entity, he will have wrong and right deeds which make up his background. Therefore, the crime by legal entity is committed under situations; and the right and wrong deeds are formed by all those involved in legal entity.

A) Commutation aspects: Clause (A) of this article refers to commutation aspects. Therefore, we should first know 
the aspects of commutation in order to find whether the commutation aspects can be applied for legal entities or not?

Article 38 refers to commutation aspects, and Clause (A) refers to plaintiff's consent. We can simply accept the fact that a legal entity with criminal responsibility and considered penalties for him such as confiscation of property and cash fine can have plaintiff; and if the plaintiff gives his consent, the commutation can be considered for this legal entity. According to Clause (B) and brain equality theory, if the manager, who is the brain of company, has effective cooperation in detection or helps to find reasons, discover property and objects or does this assistance through workers or employees in company, it will be easy to connect this clause to legal entity according to this theory. Clause (C) generally refers to victim and the specific circumstances affecting the crime commitment including the criminal's reaction to victim's behavior and action. Therefore, this clause does not include the criminal's characteristics and we can exclude the legal entity from it by excuse, but in the case of honorable motive, if the manager(s) is considered as the company brain, the manager's motivation is the sum of decision-makers and legal entity, and thus this clause simply contains the legal entity. Clause (D) refers to the criminal's execution or his confession. The execution can be connected to legal entity like a company through correspondence or other similar ways, but it is not possible for confession; and finally, we should admit that one of the these clauses, and just a part of them, not the whole one, involves the legal entity. Clause $(E)$ refers to the criminal's remorse, good reputation or special situation. For connecting this clause to legal entity, we should argue that the remorse has a personal definition and can be attributed to legal entity as it creates the sense of regret for human who has the power of distinguishing, reasoning and thinking and his emotions are originated from it. However, if this feeling is seen in behavior and actions instead of his words, can we say he is regretful? Can the legal entity compensate his mistakes and losses or not commit the past mistakes? Whether they mean regret? Therefore, the remorse can be attributed to legal entity. Furthermore, the good reputation can be attributed to him when he had not committed any crime and mistake in the past, and thus he has a good reputation like a real person. According to a simple example, when a private airline has no sign of crime in the past and its staff behaves well with people, and in short, the people are satisfied with it and there is not any bad sign in it, and the number of clients is increasing every day, and this good behavior attracts public trust; as this good look to company is also due to its well-known history otherwise people may consider it as an offender and cut their transactions with this company and refer to another company. However, in this offender's special situation, if the "aging and illness" term was not told by legislator, this clause could be fully attributed to legal entity, but the attribution of this special situation to legal entity seems farfetched due to these words. Clause (F) refers to offender's effort to commute the effects of crime or compensating the losses as same as what was described in Clause $(E)$ both for his efforts and compensation of losses and it is linked his remorse. However, the last Clause $(G)$ refers to accomplice's poor intervention in crime. According to law, the real or legal people or sum of them can participate in crime. Furthermore, a legal entity with several legal entities, or a legal entity with real person can be as the accomplice. According to the study on aspects of commutation, it is found that most of its clauses are not against the inclusion of legal entity.

B) Forecast of perpetrator correction: The court should investigate the forecast of perpetrator correction and if it is found that he will be corrected in the future, it can postpone the sentence enforcement. According to literal translation of correction, the court forecasts that the perpetrator will have behavior and activities under the law without any act or conduct against the law or any crime. Furthermore, he does good deeds in society, so that he will not commit the crime, and thus all of his behavior and actions are in a positive direction. Now, if a legal entity does a charitable act or help the charity, are they as correction and can the court forecast that he will not do any practice contrary to law? Or cannot forecast that the legal entity is regretted as described in the preceding pages and does the normal and legal activities?

C) Compensation for losses or making arrangements to compensate: It should be explicitly argued that the legal entity can compensate the losses for victim as a real person in the form of paying money or restitution of property or asking the victim wants for a deadline to agree on how the damage can be compensated. There will not be any problem in involving the legal entity in this clause, and it should be noted that this involvement is simply acceptable. It is noteworthy that the French court does not announce the above-mentioned forecast conditions in Article 60 while making decision on sentence enforcement postponement (B132, 122, 2004, Crim, 18 mai $c . n^{\circ}$ ). Meanwhile, according to Article 132 of German Penal Code, clause (a), the court can "order the criminal due to the committing crime during the sentence enforcement postponement period", and this case also indicate the consistency of our law with other countries. 
D) Lack of effective criminal record: According to clause of article, the effective condemnation deprives the convict of social rights according to execution of sentence based on Article 25 of this law. Let us now have a simple and general adaptation, Article 25 declares that the clauses (B) and (C) do not include the legal entity, but clause $(A)$ can be studied for this case because as we say the dissolution of legal entity is like death for human, thus we can attribute seven years of sentence for life depriving punishment to legal entity, while in Article 26 , clause $(L)$ reinforces this idea by referring to board establishment, department or membership in public, private and cooperative companies or brand registration; because we know that the legal entity can attend in other legal companies as the board member under the conditions in accordance with articles of commercial code; here, we do not mention them for avoiding the overstatement. At the end of this clause, it seems interesting to note that the Article 40 of IPC (Islamic Penal Code) stipulates: "the court can", so the issue of sentence enforcement postponement is among the authorities of courts. In other words, the sentence enforcement postponement is not essentially the offender right, but as an option available for court; while, according to Article 59.132 of German Penal Code, the court is not responsible for this case; and according to Article 60 of French Penal Code, the issue of this postponement is among the court's authorities. However, in some countries such as England, the detection of court based on criminal's merit is not enough, but his own satisfaction is also a fundamental condition and the judge cannot does it without an agreement with offender. It seems that since the leniency measures are not among the criminal's right, his satisfaction or dissatisfaction does not have any impact on their practices. (Tomas, 2008) The way a legal entity's satisfaction can be identified is described as follows. According to another point, the court can apply the sentence enforcement postponement for offender when he is present at hearing. This is mentioned in clause a of Article 41 of IPC (the court cannot postpone the sentence enforcement in absentia) because the court should be aware of offender's all circumstances and situation to enforce such this sentence, and this knowledge can be achieved only with perpetrator's participation in the courtroom. In this regard, the last part of Article 60: 132 of French Penal Code also mentions that the perpetrator cannot be charged unless he or his legal representative is present at the court because this is related to public order in French law and should be completely respected. (Crim, 22 mai1986, BC, $n^{\circ} 166$ )

\section{Simple or Surveillance Postponement}

According to investigation of Article 40, this article can be attributed to legal entities without perception of law; therefore, we examines different types of postponement in order to find whether we can attribute different types of postponement to legal entities or not? simple or surveillance postponement? In new law, the postponement is based on goal-setting in new law, but the alternative policy is not our attention in this study, and the legislator seeks to achieve decentralization in prison. In simple postponement, the clause (A) of Article 40 indicates that the criminal undertakes in writing not committed crime at the time set by the court and it is predicted from the way he behave that he will not committed crime in the future. Legal entity has the board, director, signatory, and employees who act as his brain and hands. Signatory managers and decision-makers decide about problems, suggestions, and criticisms which are raised about company during general or extraordinary assembly in companies. They discuss the issues which are necessary to be implemented for survival of company, and determine the issues which should be operated in line with benefits of company according to assembly members' votes. Some of the company directors or in particular the executers may be as the signatories and sign the documents on behalf of the legal entity, and thus the legal entity becomes responsible for these documents. This written commitment has the same trend; and as mentioned above, the written commitment is a kind of binding document for legal entity as he will be committed based on the representative theory.

Clause (B) of Article 41 refers to surveillance postponement and it is unlikely to cover the legal entity because when we see all aspects of surveillance postponement in Article 42, the Clause (D) refers to permission from Judicial official for traveling abroad; furthermore, the beginning of Article 42 refers to measures along with surveillance postponement; similarly, Article 43 refers to court orders requiring the offender to one of the following clauses and includes the perpetrator or his family's living conditions. Providing the clauses such as vocational training or specific professional employment, illness or addiction treatment, refusing to acknowledge all or some motor vehicles for attending in specific training courses in this article, it is concluded that this type of postponement does not contain the legal entity and not even implicitly refer to him. 


\section{Penalty Suspension}

According to article 46, which refers to penalty suspension, the court can postpone the sentence enforcement for 6 months to 2 years in Tazir crimes grading 3 to 8 after approving the criminal's individual, familial and social situation and background and the reasons for commitment of crime. Therefore, the suspension has the same conditions as postponement, and thus we only consider the conditions of postponement and its clauses assuming that the real person is included in postponement, and the penalty suspension is the same as postponement, so we do not restudy them. However, according to this part of Article 46, the criminal can ask the criminal sentence judge or prosecutor for suspension after passing one third of sentence in the case of eligibility and legal conditions. Theory of representation is true in this case as the asking the judge about sentence suspension for the one as a legal entity should be done by manager, board member, inspector or other people in company as the lawyers or representatives. As we have investigated the legal entity's right to suspension and postponement and concluded that the legal entity is included in suspension and postponement, we summarize some points as follows:

As it is said that the interpretation should be made in favor of perpetrator in order to make the laws more appropriate and easier for him, how the forecast of correcting the perpetrator can be connected only to real person, not the legal entity, and how the aspects of commutation can be considered only for legal entity. According to descriptions, the majority of this article (38) can easily involve the legal entity as well as other clauses of Article 40 as we have expressed our reasons for their inclusion in law detection. Secondly, when you look closely in clause (C) of Article 38, we find that the loss compensation can even include the financial compensation in the case of legal entity, for instance, when Tehran Blood Transfusion Organization distributed infected blood, it was obliged to pay plaintiff for compensation. Furthermore, when we have a brief look at law, i.e. article 508 of Tazir law, we find that it points out the group. Furthermore, it refers to organizational crime which is associated to legal entity because there is not an obligatory for registered legal entity to give him this feature. If it was, with what names we could identify the groups such as ISIS (Islamic State of Iraq and the Levant), Taliban and al-Qaeda.

\section{Second Issue: Investigation of Second Hypothesis}

Legal entities are not included in sentence enforcement postponement and penalty suspension.

\section{Sentence Enforcement Postponement}

In this regard, as we consider the contrary issue, we should have perception of law denial. According to of Article 20 of Islamic Penal Code (IPC), which refers to punishments for legal entities, it seems that we cannot postpone the sentence enforcement, and these sentences are not included in Article 20 for analogy. Furthermore, if we investigate these clauses in Article 40 , or the existence of commutation factors, forecast of perpetrator's correction, compensation for losses, lack of criminal background, it is concluded that despite assuming some clauses including compensation for losses for legal entity, we should consider all conditions in Article 40 as one of the clauses of perpetrator's correction refers to legal entity. Therefore, it is unlikely to decide in favor of postponement. According to another point in Article 40, it refers to individual and familial situation which is not related to legal entity; and the law rakes precaution against this new case for real people. Furthermore, the clause (D) of Article 40, which considers the lack of previous criminal record effective, has considered it as social deprivation, and Article 25 of IPC has referred to its terms and provisions such as life-depriving punishment, life imprisonment depriving, amputation, death, revenge (Qisas), and whipping and such these cases which clearly belong to real people and considered by legislator. Furthermore, the "loss compensation" indicates that the commutation aspects are seen in person, and he is investigated in terms of personality, and the remorse is seen in him, and this is true only for real person.

\section{Penalty Suspension}

In Tazir crimes grades 3 to 8, only the grades 5 and 6 consider the prohibition of invitation to raise capital for legal entity in the case that the suspension is implemented for legal entities, and thus we see the term namely "existence of provisions for sentence enforcement postponement" as explained previously, and the legislators have not considered them for legal entity. Here, if we accept this possibility, how the judge or prosecutor can ask for suspension in the case of permanent invitation prohibition to raise capital after $1 / 3$ of sentence. This question raises for both sentence enforcement suspension or postponement: How does the judge can find out that the legal entity is corrected; however, the legal entity 
is not the same motivated person who can give up; or how a legal entity can find the commutation aspects in himself while he does not have any human family or ethics, consciousness, thought and authority to which this case can be attributed. Therefore, these elements are true for real person, not for legal entities. According to Islamic Penal Code (IPC), the legislator implicitly justifies the punishment for legal entity if it resulted from the collective will and mistake; and this collective mistake will eventually refers to real person and the specified human will leading to offense. According to Article 140, this law is on contrary to Article 143; therefore, when it argues that the person should be mature and free while committing the crime, the legal entity does not have the human life and how we can attribute the wisdom, maturity and authority to him. It should be noted that the aim of sentence is to punish a person for chastising, intimidating, and preventing the person from committing the crime in the future, and I think that it is not related to legal entity which is a lifeless registered name. Therefore, how can we give the criminal responsibility to legal entity, whereas these two (real and legal) have a little difference and each one has very specific requirements; and what is determined in law as punishment for legal entity has legal aspect rather than criminal because the punishment cannot be considered for a legal entity who neither has maturity, wisdom, nor authority. Article 141 argues that the criminal responsibility is personal, and thus we cannot attribute the people's group mistake to a legal entity or punish him; but anyone is responsible for his individual behavior, and thus the individualization and personalization of punishment is questioned because we have given name to a character and punish him for other person's action and this is not according to the principle and not complied with legislator's aim at expanding justice. We cannot even tell him wise when he is punished for the other person's action.

\section{Conclusion}

We have investigated two hypotheses about legal entity's criminal responsibility and it is found that the sentence enforcement postponement and penalty suspension cannot be considered for legal entity because as described in the text, we should first find the legislator's purpose of this legal article and its clauses in Islamic Penal Code (IPC) adopted in 2013 as this law should be utilized in our country, so we should have a perception which the legislator intended in order not get in trouble and receive desired result. The legislator considers all conditions in Article 40, but does not involve all of them in hypothesis, and does not presented those sentences in Article 20 for allegory, and even has presented the terms such as individual and familial situations at the top of Article 40 in order not to make any doubt that he means real person, not legal entity.

\section{References}

Ranjbar, Hossein. (2014) "Vicarious criminal liability", Tehran, Institute of Legal Studies and Research, First edition.

Legal website of ekhtebar.ir

Islamic Penal Code (IPC) of Iran adopted in 2013.

Moin, Mohammad (2011) "Moin Dictionary", Vol. 3, Tehran, Amir Kabir Publications.

Nourbaha, Reza (2011) "General Criminal Law", Tehran, Ganje Danesh library, 31st edition.

Shambayati, Houshang, 2013. General Criminal Law, Vol. 2, Tehran, Majd, first edition.

Specialized lawyers' weblog, (dadlaw.blogfa)

Bahman Keshavarz.English-Persian Law dictionary,Tehran, Amir-Kabir Publicatin, Ninth Edition 2001.

Crim, (1986) 22 mai, B.C., n 166.

Crim, (2004) 18 mai, B.C., $n^{\circ} 122$

Grant, William, (1988) Sentence deferred- a useful Psychiatric recommendation, psychiatric Bulletin.

Hungerford - Welch, Peter, (2000) Criminal litigation and sentencing, London, Cavendish publishing, 5th ed.

Jareborg,Nils,(2005) Criminalization as last resort (Ultima Ratio), vol.2, OHIO State Journal Of Criminal law.

Thomas, David,(2008) Sentencing referencer, London, Seet \& Maxwel Lawzschool.com 